See discussions, stats, and author profiles for this publication at: https://www.researchgate.net/publication/315192173

\title{
An Insight into the Implementation of Land Use Right Transfer Policy in China: A Case Study in the City of Zhangye
}

Article in International Journal of Agricultural Resources, Governance and Ecology · July 2018

DOI: 10.1504/IJARGE.2018.10015129

CITATIONS

0

3 authors, including:

A Tomohiro Akiyama

Sophia University

91 PUBLICATIONS 107 CITATIONS

SEE PROFILE
READS

78

Ali Kharraz

International Institute for Applied Systems Analysis

40 PUBLICATIONS 234 CITATIONS

SEE PROFILE

Some of the authors of this publication are also working on these related projects:

Development of Sustainability Assessment Method View project

Public Policy Modeling and Applications View project 


\title{
An insight into the implementation of land use right transfer policy in China: a case study in the City of Zhangye
}

\author{
Haibo Fan and Tomohiro Akiyama* \\ Graduate Program in Sustainability Science - Global Leadership \\ Initiative, Graduate School of Frontier Sciences, \\ The University of Tokyo, \\ Environmental Studies Building 334, 5-1-5, \\ Kashiwanoha, Kashiwa City, \\ Chiba 277-8563, Japan \\ Fax: +81471364878 \\ Email: fanhbsaes@163.com \\ Email: akiyama@k.u-tokyo.ac.jp \\ *Corresponding author
}

\author{
Ali Kharrazi \\ Advanced Systems Analysis Group, \\ International Institute for Applied Systems Analysis (IIASA), \\ Laxenburg, Austria \\ and \\ Graduate School of Public Policy (GraSPP), \\ The University of Tokyo, \\ Tokyo, Japan \\ Email: ali@pp.u-tokyo.ac.jp
}

\begin{abstract}
Land use right transfer (LURT) has been viewed to have significant potential in advancing farmland management in China. However, the implementation of LURT policy and more specifically its effects on the local society and economy is an under-researched area. This paper provides insights into the implementation of LURT carried out in the City of Zhangye, Gansu Province. Eight villages were visited for this study and data were gathered through key informant interviews, statistical datasets and official legal documents. Our results reveal the socio-economic performance and complicated influence of LURT policy in the region. The promotion of farmers' income was confirmed in some villages and more farmers have been involved into non-agricultural sectors. However, not all farmers were satisfied with their income and contract management was somehow unsatisfying. For future improvement, policy-makers need to better tackle the ambiguous public awareness and poor management of LURT contracts.
\end{abstract}

Keywords: China; City of Zhangye; land use right transfer; policy implementation; socio-economic influence. 
Reference to this paper should be made as follows: Fan, H., Akiyama, T. and Kharrazi, A. (2018) 'An insight into the implementation of land use right transfer policy in China: a case study in the City of Zhangye', Int. J. Agricultural Resources, Governance and Ecology, Vol. 14, No. 2, pp.105-121.

Biographical notes: Mr Haibo Fan was a graduate student at Graduate Program in Sustainability Science-Global Leadership Initiative, Graduate School of Frontier Sciences in The University of Tokyo during year 2013 and 2015. He received his Bachelor's in Environmental Engineering at Tongji University, China. Recently, he has been working at Shanghai Academy of Environmental Science (SAES). His work mainly focuses on air pollution control, especially on the elimination of volatile organic compounds (VOCs), from both technique and management means.

Dr Tomohiro Akiyama is an Assistant Professor, Graduate Program in Sustainability Science-Global Leadership Initiative, Graduate School of Frontier Sciences, The University of Tokyo, Japan. He has published several articles related to the water environmental issues in Asian countries including China, Kazakhstan, Mongolia as well as some African countries such as Ghana, South Africa and so on. His academic background is hydrology, but he has been actively working for more than 16 years with researchers from other disciplines and trying to build inter- and trans-disciplinary, integrated framework for tackling global environmental problems. His academic vision is to create foundation of integral science to make a paradigm shift from modernity to post-modernity.

Ali Kharrazi is a Researcher at the Graduate School of Public Policy (GraSPP) of the University of Tokyo and at the Advanced Systems Analysis Group at the International Institute of Applied Systems Analysis (IIASA). His research focus is on advancing the concept of resilience through data-driven approaches for sustainable development goals in water, energy, food and trade systems. He is the recipient of the 2013 Green Talents Awards from the German Ministry of German Federal Ministry of Education and Research and selected as a 2015 World Social Science Fellow in Urban Big Data by the International Social Science Council. He holds a PhD in Sustainability Science from University of Tokyo, a graduate from the London School of Economics in Information Systems and University of Cambridge in Innovation, Strategy, and Organization, and a Bachelor's from the City University of New York in Economics.

\section{Introduction}

The institution of farmland ownership and use rights in China has significantly developed over time since the foundation of the People's Republic of China in 1949. Before the 1978 economic reform, land ownership and use rights were legally muddled. Although previous national constitutions of China positioned farmland as public owned, the position of how and by whom the farmland should be used remained legally vague (The National People's Congress, 1954, 1975, 1978). Yields of farmland were also considered as public owned, and farmers possessed no incentive to put effort in their cultivation. This resulted in numerous cases of land grab and land appropriation and led to serious land use inefficiencies (Gu, 2003). During the 1980s, trials of land institution 
reform were gradually promoted along with the economic reform to activate agricultural production. These approaches included allowing farmers to possess their own yields and allowing farmland to be contracted. Farmland ownership and use rights were gradually distinguished, and land use right transfer (LURT) was eventually defined by law. In 1982, the current constitution was ratified wherein it defines for the first time, the owners of land as 'The State' and 'collectives' (The National People's Congress, 1982). Furthermore, through the 1988 Constitutional Amendment, the LURT was first recognised (The National People's Congress, 1988). Therefore, as a result of the 1982 constitution and 1988 constitutional amendment, land ownership and LURT were legally clarified. Since 1990s, after nearly a decade of practice, these land institution reforms have been proven to be effective in promoting both agricultural production and rapid urbanisation (Jiang et al., 2007). Currently, the ownership of land in China follows a dual-track: i.e. state-ownership in urban areas and collective-ownership in rural areas (The National People's Congress, 2004). Regarding collectively owned land in rural areas, land use rights are allocated to farmers based on three functions, i.e., housing, privately farmed plots and contracted croplands (The National People's Congress, 2004).

The tenure of land use rights is determined by these three functions. Land use rights for housing and private farming are usually jointly allocated to farmers, for the purpose of residence and daily ration cultivation, without any tenure limit. On the other hand, land use rights of contracted cropland are allocated to households for the purpose of commodity crop cultivation, with an extendable tenure of 30 years (The National People's Congress, 2004). The function of lands can be changed only with governmental approval. Based on this premise, the government practices some flexibility on the management of rural lands. Housing and privately farmed plots, although collectively owned by the local community de jure, are considered by farmers as their individual property ( $\mathrm{Li}$ et al., 1998). Households in some villages even possess the freedom to bequeath their housing and privately farmed plot to their children (Brandt et al., 2002). With respect to contracted cropland, farmers maintain the option of outsourcing the land use right to others - with the premise of keeping the land for purpose of crop cultivation. In this case, the land use rights of those farmlands are outsourced, i.e. transferred, as a de facto commodity, while the local community is still the subject of the contract de jure.

Land use right transfer on contracted cropland has been of great significance in China's agricultural economy. On one hand, among the three functions, contracted cropland is dominating rural land use, in terms of total area. The latest statistical area of contracted cropland was published as $18.26 \times 10^{8} m u^{1}\left(12,171.59 \times 10^{4} \mathrm{hm}^{2}\right)$ for the whole China in 2008 (National Bureau of Statistics of China, 2014) ${ }^{2}$. Regarding housing area, Song et al. (2008) estimated a $1.367 \times 10^{8} \mathrm{mu}\left(911.61 \times 10^{4} \mathrm{hm}^{2}\right)$ for the year 2005 ; the Economic Information Daily (2014) said a $1.7 \times 10^{8} \mathrm{mu}\left(1,133.34 \times 10^{4} \mathrm{hm}^{2}\right)$ for the year 2013, whereas He (2015) suggested a $2.5 \times 10^{8} \mathrm{mu}\left(1,666.68 \times 10^{4} \mathrm{hm}^{2}\right)$ for 2014 . The area of contracted cropland is 7.3 times of the estimation of $\mathrm{He}$ (2015) for housing, and 29.2 times of privately farmed plot. Therefore, LURT on contracted cropland significantly influences rural agricultural production. On the other hand, governments attach great importance to LURT policy. Indeed, it was promoted as a strategy for the further market liberalisation of the agricultural economy since 2003 (Sixteenth Central Committee of the Communist Party of China, 2003). It has also been expected to increase agricultural mechanisation, farmland yields, income of farmers and availability of youth labour towards higher value-added economic sectors. The high expectation attached to 
the LURT policy by the government necessitates the need to investigate the success of its implementation and obtain insights into its social and economic affects.

China's land use right issue has been a controversial topic that has attracted the attention of many researchers. Numerous research publications have been concerned with the land use right system and its institutional change (Brandt et al., 2002; Ho and Lin, 2003; Ding, 2003, 2007; Zhu, 2004). Several researchers have focused on the impact of land institutions on land use efficiency from various perspectives (Li et al., 1998; Carter and Yao, 2002). The land tenure security issue, based on the current property right system, has also received the attention of researchers (Li et al., 1998; Kung, 2000; Krusekopf, 2002). Other researches have focused on specific related topics. For example, Liu et al. (1998) discuss the internal conflict of interests between stakeholders, including owners, contractors, cultivators and governors. Specific to LURT, Du and Sun (2011) presents an empirical discussion on LURT institutions, and Liu (2012) focuses on the positions of the LURT institutions vis-a-vis the 'New Countryside Construction' national policy program. Nevertheless, there is a gap in the literature providing insights into the implementation of LURT policies and their socio-economic effects based on case studies. With the aim of contributing in this area, this paper examines the implementation of LURT policies in Gaotai County, Zhangye City, in northwest China. This paper is organised as follows: Section 2 introduces the study area and data collection methodology for this research. Section 3 introduces the implementation of LURT policies at Gaotai County and analyses the corresponding socio-economic effects. A discussion and concluding thoughts on the advantages and disadvantages of LURT policy are followed in Section 4.

\section{Materials and methods}

\subsection{Study area}

Zhangye City, located in the middle reaches of the Heihe River basin, is the second largest inland river basin in China (Figure 1a). The city holds jurisdiction over 60 towns consisting of 835 administrative villages, which further contains 5,965 'Villager Groups', or 'Production Teams' as its previous name, as the basic unit for administration and agricultural production in rural China (Wang, 2014). In total, 741.9 thousand citizens in 271.4 thousand households serve as the agricultural population in this area (Wang, 2014; Li, 2014). Despite being close to the third biggest desert in China, i.e. the Badain Jaran Desert, Zhangye benefits from the Heihe River and is dependent on its agriculture sector. Zhangye is a major producer of seed corn in China, with a yield of $32.2 \times 10^{4}$ tons in 2014 - this counts as $32 \%$ of China's total seed corn production (Zhangye Agricultural Bureau, 2015). In 2011, the primary sector contributed $28.1 \%$ to the total GDP in Zhangye City (Xian, 2013). 
Figure 1 (a) Location of Heihe River basin and Zhangye city within China. (b) Detailed map of Gaotai County in the middle reaches of Heihe River basin
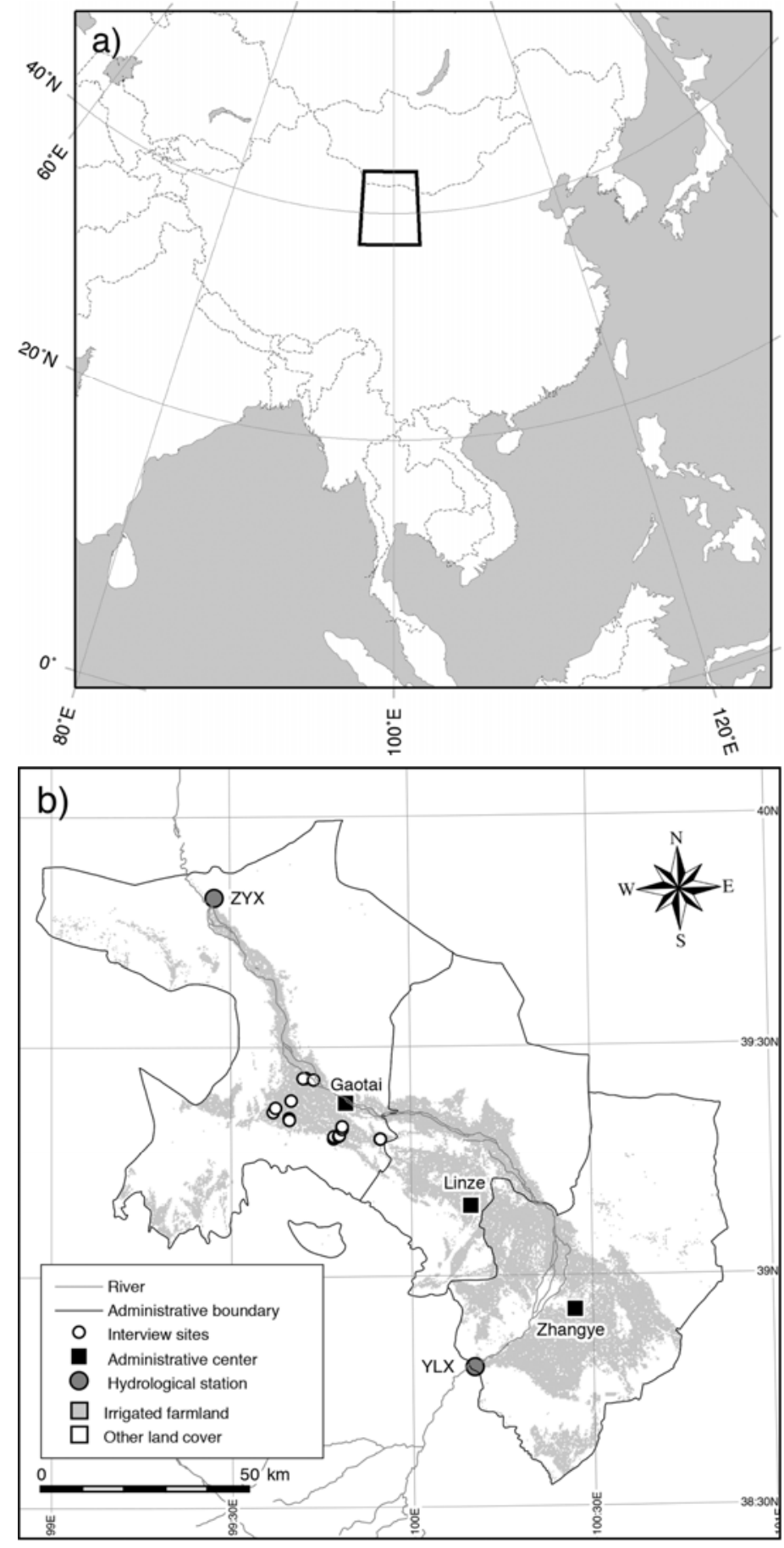
The local government of Zhangye has been largely promoting LURT since 2009 ( $\mathrm{Li}, 2014)$. In 2014, the land use right of $26.3 \%$ of the total farmland in Zhangye was transferred, i.e., 1.023 million $m u\left(6.82 \times 10^{4} \mathrm{hm}^{2}\right)$ out of the total 3.89 million $m u(25.93$ $\times 10^{4} \mathrm{hm}^{2}$ ) of arable land. This amounted to approximately $670 \%$ more LURT than 2007 (Wang, 2014). Given the strong promotion by the local government and test pilot position as a large-scale LURT policy, the City of Zhangye proved to be an ideal case study for this research. As a traditional oasis agriculture-based city, Zhangye shares quite a few commonalities, in terms of climate, natural environment, urbanisation process and ecological threshold, with other cities located in the semi-arid regions of China and the Hexi Corridor (Qiao et al., 2006). Therefore, the case study of Zhangye provides insight into LURT policy implementation which will also serve as a good reference to other cities under similar conditions in China.

Gaotai County, located in the west of Zhangye (Figure 1b), is a predominantly rural and agriculture-dependent county, with an $82 \%$ rural population and a $40 \%$ GDP from primary sector in 2007 (Du, 2012). The total arable land area in Gaotai County was 58.91 $\times 10^{4} \mathrm{mu}\left(3.93 \times 10^{4} \mathrm{hm}^{2}\right)$ in 2014 , from which the land use right of $8.6 \times 10^{4} \mathrm{mu}(5.73 \times$ $10^{3} \mathrm{hm}^{2}$ ) had been transferred ( $\left.\mathrm{Li}, 2014\right)$. Figure $1 \mathrm{~b}$ illustrates the map of villages that have been visited in the field survey. Eight villages scattering in three towns were involved. They are expressed as XF Village, ZH Village and XHZ Village at NH Town; QJ Village, HX Village and JK Village at LTC Town; and XH Village and ZJP Village at XH Town. They all contained certain degree of LURT.

\subsection{Data collection}

Data for this research were collected using a triangulation analysis of key informant interviews, statistical data and legal documents. Data triangulation enabled the validation of results and evidence building for this research (Hennink et al., 2010). Data collection was mainly conducted during a field survey at Gaotai County from August 3 to August 13, 2014. Key informant and villagers' interviews served as core methodology in the field survey. A total number of 20 in-depth interviews were conducted, including 10 farmers as lessors, 3 governmental officials, 2 'Villager Group' leaders, 1 cooperative operator, 2 private agricultural company managers and 2 farmers as individual subcontractors. All the interviews were semi-structured with some bundles of common questions yet an unconstrained format and more individualised questions. The question bundles involve various aspects, including, but not limited to, management of LURT practice; support from the government; the family's labour situation and attitudes towards LURT policies; farmers' hourly wage; and the target market for production and annual income and expenses. Besides the interview survey, a number of raw statistical data as well as legal documents from the local government were collected.

\section{Results}

\subsection{How is LURT policy implemented at Gaotai County?}

According to Zhangye Statistics Bureau, the five major LURT modes (Table 1) in the Zhangye include the leasing mode, outsourcing mode, exchange mode, stake sharing mode and commission mode (Wang, 2014). Leasing mode refers to the transfer of land 
between farmers and local production cooperatives (Or co-ops: self-organised indigenous agribusiness firms), and major farmland holding families (dahu families). Outsourcing mode refers to land transfer from farmers to other third-party companies. Exchange mode refers to exchange of land among farmers for the convenience of cultivation. Stake sharing mode refers to land use rights to be utilised as a 'stake' in joint management and profit. Finally, commission mode refers to the commissioning of land use right by farmers to friends, due to their inability to cultivate the land by themselves, without the demand of any profit.

Table 1 LURT transfer modes (Grey shows transfer modes identified in this study)

\begin{tabular}{|c|c|c|}
\hline $\begin{array}{l}\text { Land use right } \\
\text { transfer mode }\end{array}$ & $\begin{array}{l}\text { Transfer objectives } \\
\text { (sub-contractors) }\end{array}$ & Description \\
\hline Leasing mode & $\begin{array}{l}\text { hezuoshe (cooperative, self- } \\
\text { organised indigenous } \\
\text { agribusiness firm) or dahu } \\
\text { (rich families) }\end{array}$ & Mainly local sub-contractor \\
\hline Outsourcing mode & Third-party companies & Mainly non-local sub-contractor \\
\hline Exchange mode & Other farmers & $\begin{array}{l}\text { For the sake of cultivation convenience } \\
\text { (land consistency) }\end{array}$ \\
\hline Stake sharing mode & $\begin{array}{l}\text { hezuoshe or third-party } \\
\text { companies }\end{array}$ & $\begin{array}{l}\text { The use right of land is utilised as 'stake' } \\
\text { for a joint management and profit }\end{array}$ \\
\hline Commission mode & Friends (farmers) & $\begin{array}{l}\text { Farmers commission their land use right } \\
\text { to friends due to an inability of } \\
\text { cultivating by themselves without asking } \\
\text { for any profit }\end{array}$ \\
\hline
\end{tabular}

In our field survey, only two transfer modes mentioned above were found. Five cooperatives and five farmers belonging to dahu families in our interview were practicing the leasing mode to sub-contractors. Furthermore, LURT to five private companies under the outsourcing mode was also observed. According to Wang (2014), the leasing and outsourcing modes, in terms of area transferred, accounted, respectively, for $75.3 \%$ and $13.3 \%$ share of total LURT. The findings of our survey also correspond to the above proportion and indicate leasing and outsourcing as the major modes among LURT.

The detailed list of total farmland areas and number of households involved in LURT among the villages of the NH Town from year 2011 to 2013 is provided in Table 2 . Similarly, Table 3 shows the information at the LTC Town since year 2009 up to the year 2014. From 2011 to 2013 , NH Town transferred $1.36 \times 10^{4} \mathrm{mu}^{3}$ out of the total approximate $3.49 \times 10^{4} \mathrm{mu}$ cultivated farmland (Gansu Rural Yearbook Committee, 2010). Since 2014, NH Town has been promoting the development of vegetable cultivation by making the transferred land into a 'Vegetable industry park'. From 2011 to 2013, the area of transferred farmland in each year at NH town shrank slightly year by year. The decreasing trend may be attributed to the decreasing availability of land for LURT as more and more land has been previously transferred. On the other hand, the area of transferred land at LTC Town stood at $1.36 \times 10^{4} \mathrm{mu}$ out of a total $6 \times 10^{4} \mathrm{mu}$ until the year 2014, with more farmland being transferred in 2014 than the sum of all the years before. Moreover, transferred land at XH Town reached $1.03 \times 10^{4} \mathrm{mu}$, out of its total $3.52 \times 10^{4} \mathrm{mu}$ farmland, which also shows a booming trend. Overall, the statistical evidence indicates a general boom of LURT market in recent years. 
Table 2 Area and households involved in LURT at NH Town (2011-2013) (Area unit: $m u$ )

\begin{tabular}{|c|c|c|c|c|c|c|c|c|c|c|}
\hline Village & $\begin{array}{c}\text { LURT } \\
\text { area } \\
(2011- \\
2013)\end{array}$ & $\begin{array}{c}\text { LURT } \\
\text { area } \\
(2011)\end{array}$ & $\begin{array}{c}\text { Households } \\
\text { involved } \\
\text { (2011) }\end{array}$ & $\begin{array}{l}\text { Farmer's } \\
\text { population } \\
\text { involved } \\
\text { (2011) }\end{array}$ & $\begin{array}{c}\text { LURT } \\
\text { area } \\
\text { (2012) }\end{array}$ & $\begin{array}{l}\text { Households } \\
\text { involved } \\
\text { (2012) }\end{array}$ & $\begin{array}{c}\text { Farmer's } \\
\text { population } \\
\text { involved } \\
\text { (2012) }\end{array}$ & $\begin{array}{c}\text { LURT } \\
\text { area } \\
\text { (2013) }\end{array}$ & $\begin{array}{l}\text { Households } \\
\text { involved } \\
\text { (2013) }\end{array}$ & $\begin{array}{c}\text { Farmer's } \\
\text { population } \\
\text { involved } \\
\text { (2013) }\end{array}$ \\
\hline XHZ & $3,874.52$ & $2,622.52$ & 130 & 494 & 1,252 & 86 & 403 & & - & - \\
\hline DR & $1,370.18$ & $1,295.18$ & 74 & 323 & 75 & 43 & 198 & & - & - \\
\hline $\mathrm{DZ}$ & 830 & & & & 170 & 15 & 70 & 660 & - & - \\
\hline NZZ & $1,246.2$ & 600 & 78 & 230 & 558.2 & 42 & 198 & 88 & - & - \\
\hline YH & $1,015.9$ & 614.9 & 74 & 290 & & & & 401 & - & - \\
\hline $\mathrm{ZH}$ & 515 & & & & 515 & 42 & 198 & & - & - \\
\hline LH & $3,316.59$ & & & & $3,316.59$ & 243 & 925 & & - & - \\
\hline $\mathrm{NC}$ & 506 & 506 & 109 & 429 & & & & & - & - \\
\hline XIH & 450 & & & & & & & 450 & - & - \\
\hline $\mathrm{CH}$ & $1,212.9$ & $1,212.9$ & 60 & 231 & & & & & - & - \\
\hline MS & 203.8 & 203.8 & 22 & 90 & & & & & - & - \\
\hline MY & 174.11 & & & & 174.11 & 9 & 45 & & - & - \\
\hline YJ & 189.65 & 89.65 & 11 & 50 & 100 & 8 & 35 & & - & - \\
\hline Total & $14,904.85^{\mathrm{a}}$ & $7,144.95$ & 558 & 2,137 & $6,160.9$ & 488 & 2,072 & 1,599 & - & - \\
\hline
\end{tabular}

${ }^{a}$ This number is an accumulative sum from year 2011 to 2013 instead of actual total area that carried out LURT at the end of 2013

Table 3 Area and households involved in LURT at LTC town (Area unit: $m u$ )

\begin{tabular}{lccccccc}
\hline LURT & $\begin{array}{c}\text { LURT } \\
\text { area } \\
\text { area }\end{array}$ & $\begin{array}{c}\text { Households } \\
\text { involved } \\
(-2013)\end{array}$ & $\begin{array}{c}\text { Farmer's } \\
\text { population } \\
\text { involved } \\
(-2013)\end{array}$ & $\begin{array}{c}\text { LURT } \\
\text { area } \\
(2014)\end{array}$ & $\begin{array}{c}\text { Households } \\
\text { involved } \\
(2014)\end{array}$ & $\begin{array}{c}\text { Farmer's } \\
\text { population } \\
\text { involved } \\
(2014)\end{array}$ \\
\hline JQZ & $1,859.1$ & 1,600 & - & - & 259.1 & 17 & 64 \\
WT & 499 & & - & - & 499 & 38 & 112 \\
XL & 357 & & - & - & 357 & 4 & 11 \\
HX & 2,630 & & - & - & 2,630 & 143 & 506 \\
TJ & 540 & 240 & - & - & 300 & 1 & 3 \\
JK & 1,950 & 770 & - & - & 1,180 & 50 & 180 \\
YS & 420 & & - & - & 420 & 16 & 57 \\
QJ & 4,414 & 2,000 & - & - & 2,414 & 36 & 98 \\
XJ & 500 & & - & - & 500 & 3 & 10 \\
XT & 400 & 400 & - & - & & 30 & 126 \\
Total & $13,569.1$ & 5,010 & - & - & $8,559.1$ & 338 & 1,167 \\
\hline
\end{tabular}




\subsection{How is LURT contract operated at Gaotai County?}

The level of government involvement with the LURT can be categorised as either Type A direct involvement or Type B indirect involvement. The stakeholders and flows of these two contract categories are illustrated in Figure 2. In Type A contracts, farmers participating in LURT will approach the Village Committee who will subsequently represent farmers in leasing land to contractors. In this case, farmers usually are not aware of the identity of the contractors before their land use rights are transferred. In Type B contracts, the government indirectly assists farmers to sign contract with contractors. Furthermore, in Type B contracts, the government provides judicial and arbitration services, and assists the settlement of disputes between the signing parties. In our field survey, we found that $\mathrm{NH}$ Town and $\mathrm{XH}$ Town followed Type A contracts, whereas LTC Town followed Type B contracts.

Figure 2 LURT contract types

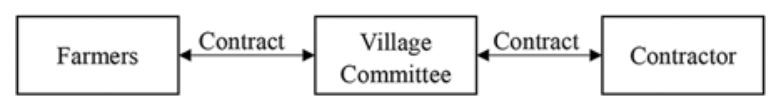

Type A. Government direct involvement

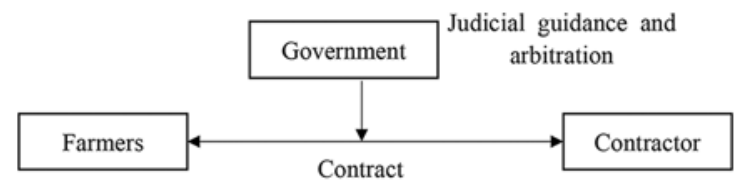

Type B. Indirect government assistance

Among the two types of contracts discussed above, various contract terms were observed. These terms and their corresponding contract types are summarised in Table 4. In our survey, we observed four cases from $\mathrm{NH}$ Town where 30 -year contract terms were practiced. In one case at XF Village, NH Town, the land use right was allocated to one farmer at 1995 by the village with a 30-year tenure. In 2013, this farmer signed an LURT contract with another 30-year term. The contract term actually exceeded the tenure of land use right which will be due on 2025. For the sake of its legal validation therefore, the contract term was divided into two parts. The first part was a 12 -year period, from 2013 to 2025, and the second part was an 18-year period, from 2025 to 2043. The second part of the contract will automatically come into effect when the farmer's 30-year land use rights are extended by the government in 2025. Shorter contract terms, on the other hand, i.e., from 1 to 5 years, were also observed in NH Town. In XH Town, 3-year contract terms were the practiced norm, whereas no contracts exceeding a 6-year term were observed in LTC Town. 
Table 4 LURT contract modes, terms and corresponding cases

\begin{tabular}{lccc}
\hline Contract mode & Description & Contract term & Cases \\
\hline Mode A. & Government directly & 30 years & XF Vil. (NH Town) \\
& involved in contract & & ZH Vil. (NH Town) \\
& endorsement as a party & $3-5$ years & XF Vil. (NH Town) \\
& & & XHZ Vil. (NH Town) \\
& & & ZH Vil. (NH Town) \\
& & Less than 3 & LH Vil. (NH Town) \\
& & years & XIH Vil. (NH Town) \\
& & & villages throughout XH Town \\
Mode B. & Government indirectly & $3-6$ years & HX Vil. (LTC Town) \\
& assisted other parties in & & QJ Vil. (LTC Town) \\
& contract endorsement & & QJ Vil. (LTC Town) \\
& & & JQZ Vil. (LTC Town) \\
& & Less than 3 & HX Vil. (LTC Town) \\
& & years & JK Vil. (LTC Town) \\
\hline
\end{tabular}

Figure 3 shows the schematic diagram of the four major business models being practiced in the study area. In the first model, farmers outsourcing their land use rights to companies are subsequently employed by the same companies to work on those farmlands. In the second model, after receiving LURT from farmers, companies subcontract the use rights to 'dahu families' whom employ farmers to work on the lands. I In third and fourth models, the farmers outsource their land use rights to, respectively, 'dahu families' and cooperatives.

Figure 3 A schematic diagram of four major business models in LURT practice

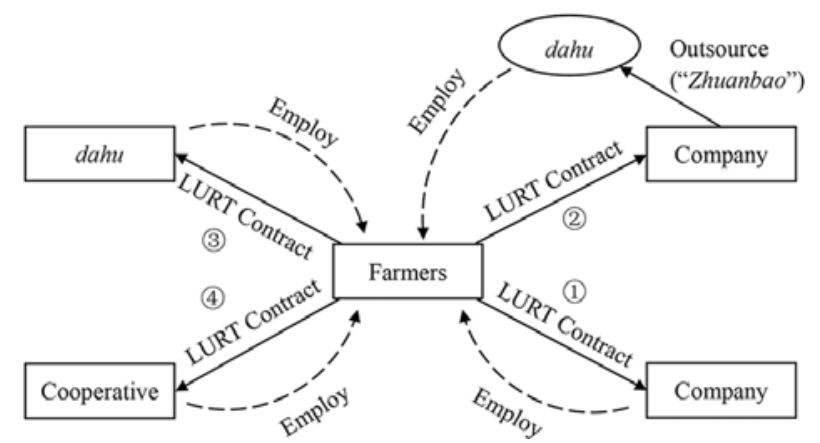

Despite the different contracts models, it was commonly observed that most farmers, 5 out of 11 of farmers interviewed, would eventually work on their own or nearby farmlands. Ironically, these contracts would only change the position of farmers, from land use right holders to employees of the sub-contractors, while still tying them to the land. The only difference between the first, third and fourth contract models is the subcontractor and farmers are directly employed. In the second model, as a result of the labour shortage, land cultivation is outsourced to dahu families. In the second model, the 
company plays the role of manager, marketer and quality controller, and is not directly involved in the cultivation process.

\subsection{How does LURT policy affect sustainable agriculture and crop structure?}

For a more resilient human-environmental coupled system, sustainable agricultural practices emphasise the necessity for higher crop diversity. While the region enjoys high levels of seed-diversity, the potentials for high crop diversity have been limited due to the structure of the market. The agricultural market of the areas we surveyed is heavily influenced by fertility, geographical fragmentation of the farmland and existing supplydemand networks. In general, it was observed that both higher LURT activity and land rent were correlated with the larger farmlands and crop yield fertility conditions. This was best seen while comparing the effect of LURT policy between NH and LTC town, whereby the first has lower average levels of farmland per household (Table 2), crop yield, lower rent (Table 5) and lower LURT activities.

Table 5 Rent of transferred land at LTC Town and NH Town

\begin{tabular}{lccc}
\hline $\begin{array}{l}\text { Village } \\
\text { (LTC Town) }\end{array}$ & $\begin{array}{c}\text { Rent } \\
(\text { RMByuan/mu.yr })\end{array}$ & $\begin{array}{c}\text { Village } \\
(\text { NH Town })\end{array}$ & $\begin{array}{c}\text { Rent } \\
(\text { RMByuan } / \text { mu.yr })\end{array}$ \\
\hline JQZ & 950 & XHZ & 600,700 \\
WT & 850 & DR & $500-700$ \\
XL & 700 & DZ & $400-800$ \\
HX & 800 & NZZ & 500,800 \\
TJ & 700 & YH & 700,800 \\
JK & 1,000 & ZH & 800 \\
YS & 1,000 & LH & $675.5,700$ \\
QJ & 700 & NC & 500 \\
XJ & 650 & XIH & 800 \\
XT & 1,100 & CH & 700 \\
& & MS & 500 \\
& & MY & 900 \\
& & YJ & $500-800$ \\
Range & $650-1,100$ & Range & $400-900$ \\
\hline
\end{tabular}

What is certain is that despite the limitations of available land, LURT policy should take a stronger approach in promoting a more entrepreneurial agricultural market. Although seed and edible corns are dominant in the cultivation structure, as can be seen in Tables 6 and 7 , there is substantial diversity in the selection of other crops. The selection of crops, however, is heavily influenced by pre-existing market channels. Pre-existing market channels are beneficial in lowering transactions costs; however, for incoming stability, individual farmers tend to not switch and experiment with new crops. Nevertheless, our results reveal more flexibility by cooperatives and companies to switch crop structures and tune their activities to benefit from new market opportunities. Contract farming also significantly influenced the selection of crops. Contract farming is a type of farming 
whereby farmers reach agreements on the selection of crops with the crop merchants. The effects of pre-existing market channels were most notably seen through the practice of contract farming. In our surveys, contract farming was seen among the activities of onion merchants and contracts with ketchup-producing factories.

Table 6 Cropping structure on transferred land

\begin{tabular}{|c|c|c|c|c|c|c|c|c|c|c|c|c|}
\hline \multirow[b]{2}{*}{ Village } & \multirow[b]{2}{*}{ Town } & \multicolumn{11}{|c|}{ Vegetation } \\
\hline & & $\begin{array}{l}\text { Seed } \\
\text { corn }\end{array}$ & $\begin{array}{c}\text { Edible } \\
\text { corn }\end{array}$ & Wheat & Cabbage & $\begin{array}{l}\text { Chinese } \\
\text { cabbage }\end{array}$ & Tomato & Cauliflower & Sunflower & Radish & Onion & Chili \\
\hline $\mathrm{XF}$ & $\mathrm{NH}$ & $\sqrt{ }$ & $\sqrt{ }$ & & & & & & & & & $\sqrt{ }$ \\
\hline $\mathrm{ZH}$ & $\mathrm{NH}$ & & & & $\sqrt{ }$ & $\sqrt{ }$ & & $\sqrt{ }$ & & $\sqrt{ }$ & & \\
\hline XHZ & $\mathrm{NH}$ & & $\sqrt{ }$ & & & & $\sqrt{ }$ & & $\sqrt{ }$ & $\sqrt{ }$ & $\sqrt{ }$ & \\
\hline SL & $\mathrm{NH}$ & $\sqrt{ }$ & $\sqrt{ }$ & $\sqrt{ }$ & & & & & $\sqrt{ }$ & $\sqrt{ }$ & & \\
\hline QJ & LTC & & $\sqrt{ }$ & & & & & & & & $\sqrt{ }$ & \\
\hline JK & LTC & & $\sqrt{ }$ & & & & & & & & $\sqrt{ }$ & \\
\hline HX & LTC & $\sqrt{ }$ & & & & & & & & & & \\
\hline XH & $\mathrm{XH}$ & & & & & & & & $\sqrt{ }$ & & & \\
\hline ZJP & $\mathrm{XH}$ & & & & & & $\sqrt{ }$ & & & & $\sqrt{ }$ & $\sqrt{ }$ \\
\hline
\end{tabular}

Table 7 Cropping structure and cultivated area on transferred land at LTC Town (area unit: $m u)$

\begin{tabular}{|c|c|c|c|c|c|}
\hline \multirow[b]{2}{*}{ Village } & \multirow{2}{*}{$\begin{array}{l}\text { LURT area } \\
(-2014)\end{array}$} & \multicolumn{4}{|c|}{ Cultivated area at transferred land (2014) } \\
\hline & & Seed corn & Edible corn & Onion & Sunflower \\
\hline JQZ & $1,859.1$ & & $1,859.1$ & & \\
\hline WT & 499 & & & 499 & \\
\hline XL & 357 & & 250 & 107 & \\
\hline HX & 2,630 & 2,630 & & & \\
\hline $\mathrm{TJ}$ & 540 & & 300 & 240 & \\
\hline $\mathrm{JK}$ & 1,950 & & 770 & 1,180 & \\
\hline YS & 420 & & & 420 & \\
\hline QJ & 4,414 & & 3,414 & 1,000 & \\
\hline $\mathrm{XJ}$ & 500 & & & & 500 \\
\hline $\mathrm{XT}$ & 400 & & & 400 & \\
\hline Total & $13,569.1$ & 2,630 & $6,593.1$ & 3,846 & 500 \\
\hline
\end{tabular}

The ability to develop a more entrepreneurial agricultural market through LURT policy was also significantly influenced by individual incentives. As seen in Tables 8 and 9, the attitudes of farmers are based on their age and ability to work. Specifically, we observed that a majority of farmers who were in good health believed that self-cultivation provided higher incomes than LURT contracts, whereas farmers with low health had opposite attitudes. An important factor in shaping these attitudes is that most LURT contracts require farmers to bear the costs of maintaining irrigation wells and therefore forego more of their actual profits. Overall, the priority of all farmers was observed to lie in 
finding employment opportunities in urban areas, where they could earn higher salaries. Hence, on one hand, LURT policy was viewed as liberating labour mobility and providing an opportunity for work elsewhere without completely wasting their farmland. However, on the other hand, LURT policy has been less successful in promoting a more diverse agricultural market with ample individual incentives for entrepreneurial activities.

Table 8 Public participation and attitude towards LURT practice (Interview data only)

\begin{tabular}{|c|c|c|c|c|c|c|c|c|c|c|c|c|}
\hline \multirow{2}{*}{$\begin{array}{l}\text { Participation } \\
\text { basis }\end{array}$} & \multirow[b]{2}{*}{ Town } & \multirow[b]{2}{*}{ Village } & \multicolumn{4}{|c|}{ Farmers } & \multicolumn{2}{|c|}{$\begin{array}{l}\text { Local } \\
\text { cadres }\end{array}$} & \multicolumn{3}{|c|}{$d a h u$} & \multirow{2}{*}{$\frac{\text { Stakeholders }}{\text { Attitude }}$} \\
\hline & & & Pro & Ambiguous & Con & Lobbied & Pro & Con & Pro & Neutral & Con & \\
\hline \multirow{5}{*}{$\begin{array}{l}\text { Villager } \\
\text { group } \\
\text { (Production } \\
\text { team) }\end{array}$} & $\mathrm{NH}$ & $\mathrm{XF}$ & & 3 & & 3 & 1 & & & & & \multirow{8}{*}{$\begin{array}{c}\text { Number of } \\
\text { people }\end{array}$} \\
\hline & & $\mathrm{ZH}$ & & & 2 & 1 & 2 & & & 1 & & \\
\hline & & XHZ & & & & & & & & & 1 & \\
\hline & $\mathrm{XH}$ & $\mathrm{XH}$ & & & 1 & 1 & & & & & & \\
\hline & & ZJP & 1 & & & & & & & & & \\
\hline \multirow{3}{*}{$\begin{array}{l}\text { Individual } \\
\text { household }\end{array}$} & LTC & QJ & 1 & & & & & & & & & \\
\hline & & $\mathrm{JK}$ & & & 2 & 1 & & & & & & \\
\hline & & HX & & 1 & & & & & & & & \\
\hline
\end{tabular}

Table 9 Attitude towards LURT and reasons based on age groups and household situation

\begin{tabular}{|c|c|c|c|c|}
\hline $\begin{array}{l}\text { Major household } \\
\text { members age group }\end{array}$ & \multicolumn{2}{|c|}{ Household situation } & $\begin{array}{l}\text { Willingness } \\
\text { to land } \\
\text { transfer }\end{array}$ & Reasons \\
\hline \multirow[t]{4}{*}{$\begin{array}{l}\text { Elder (People in their } \\
\text { late } 40 \text { s or beyond) }\end{array}$} & \multirow{2}{*}{\multicolumn{2}{|c|}{$\begin{array}{l}\text { Healthy enough for } \\
\text { agricultural work }\end{array}$}} & $\begin{array}{l}\text { Not willing } \\
\text { to }\end{array}$ & $\begin{array}{l}\text { More income if land is cultivated } \\
\text { by themselves; }\end{array}$ \\
\hline & & & & $\begin{array}{l}\text { Too old to work in non- } \\
\text { agricultural sectors }\end{array}$ \\
\hline & \multirow{2}{*}{\multicolumn{2}{|c|}{$\begin{array}{l}\text { Too weak to do } \\
\text { agricultural work }\end{array}$}} & Willing to & $\begin{array}{l}\text { Cannot cultivate even without } \\
\text { land transfer; }\end{array}$ \\
\hline & & & & $\begin{array}{l}\text { Too old to work in non- } \\
\text { agricultural sectors }\end{array}$ \\
\hline \multirow{8}{*}{$\begin{array}{l}\text { Youth and middle- } \\
\text { aged (People in their } \\
20 \text { s, } 30 \text { s and early } \\
40 \text { s) }\end{array}$} & \multirow{6}{*}{$\begin{array}{l}\text { Supporting } \\
\text { elders or } \\
\text { kids in } \\
\text { family }\end{array}$} & \multirow{3}{*}{$\begin{array}{l}\text { Elders } \\
\text { healthy } \\
\text { enough }\end{array}$} & $\begin{array}{l}\text { Not Willing } \\
\text { to }\end{array}$ & $\begin{array}{l}\text { More income if land is cultivated } \\
\text { by elders; }\end{array}$ \\
\hline & & & & $\begin{array}{l}\text { Youth could work in non- } \\
\text { agricultural sectors; }\end{array}$ \\
\hline & & & & Elders could take care of kids \\
\hline & & \multirow{3}{*}{$\begin{array}{l}\text { Elders } \\
\text { not } \\
\text { healthy } \\
\text { enough }\end{array}$} & Willing to & $\begin{array}{l}\text { Youth is able to work in non- } \\
\text { agricultural sectors; }\end{array}$ \\
\hline & & & & $\begin{array}{l}\text { Elders can't cultivate even } \\
\text { without land transfer; }\end{array}$ \\
\hline & & & & $\begin{array}{l}\text { Elders could take care of kids and } \\
\text { get land rent at the same time }\end{array}$ \\
\hline & \multirow{2}{*}{\multicolumn{2}{|c|}{$\begin{array}{l}\text { No need for } \\
\text { supporting elders or } \\
\text { kids in family }\end{array}$}} & Willing to & $\begin{array}{l}\text { Youth is able to work in non- } \\
\text { agricultural sectors; }\end{array}$ \\
\hline & & & & $\begin{array}{l}\text { Could get land rent at the same } \\
\text { time }\end{array}$ \\
\hline
\end{tabular}




\section{Discussion and conclusion}

In this paper, we examined the social and economic issues and challenges surrounding the Chinese LURT policy through the case of the Zhangye City. The booming LURT contracts in the City of Zhangye have had mixed results for the local society. Several benefits have been developed due to LURT, including efficiency improvement in agriculture production (Jiang et al., 2007), labour liberation and the promotion of grassroots democracy.

First, concerning improvement in agriculture production, LURT is indeed considered as an efficient means of land resource redistribution (Wang, 2014). China's previously completely centralised land administrative institutions have been criticised as defective by many scholars (Carter and Yao, 2002; Zhu, 2004). In comparison to previous institutions, LURT policy has made major inroads in the introduction of market-based mechanisms in land administration. First, comparing to cultivation by scattered farmers, LURT policy allows farmlands to be managed in larger scales by companies with technical know-how and investable capital. Machines together with better planting technique are encouraged, which improves level of mechanisation and efficiency. As a result, the rural land market and agriculture production become more activated.

Second, with regard to labour liberation, LURT policy has undoubtedly boosted the migration of labour from rural to urban areas as well as from agricultural to nonagricultural economic sectors. Farmers believe that working in non-agricultural sectors provides higher income than in agricultural sectors and LURT offered them the opportunity to do so without wasting their farmland. Between 2007 and 2011, the population in Gaotai County working in the agricultural sectors has dropped $5.3 \%$ $(\mathrm{Du}, 2012)$ - this indicates a positive trend in labour migration to urban areas.

Third, LURT promotes the practice of grass-root democracy. Apparently, lobbying from village leaders left a strong mark on farmers' decision (Table 8), for example, 6 out of 11 farmers reported that they had been lobbied. However, the decision-making procedure was still transparent and compliant with laws and regulations. Farmers followed the simple principle of "Minority goes subordinate to majority", which undoubtedly manifested a democratic spirit at grass-root level in a certain sense.

One case is worthy of mentioning in terms of creating a more entrepreneurial agricultural market due to the existence of LURT. Through our investigation, we found out a cooperative at HX Village, LTC Town. Named after TFWK, this cooperative followed Model 2 (Figure 3) in its business running. The originality of this cooperative is that it introduced many new tactics for the traditional agricultural production. By hiring specialists for professional field management and precise irrigation, the co-op produces pesticide-free high-quality vegetables. Moreover, it developed its marketing channel through online advertising and shopping, and it also provided agriculture experiencing service for urban citizens. The high value-added products and novel marketing channel is believed to bring about more opportunities to an emerging market. The success of this case partly demonstrates LURT is capable to encourage a more dynamic and entrepreneurial agricultural market.

In spite of the advantages from booming LURT in the City of Zhangye, certain disadvantages of present LURT do exist. They include drawbacks in terms of LURT contract management, economic performance and public participation. First, regarding LURT contract management, special concern has been exhibited by villagers particularly towards the 30 -year term contract. This concern is reasonable because such a long 
duration makes it easier for farmers to lose their control over the farmland. To avoid such a problem, a more standardised LURT contract management is required.

Second, in terms of economic performance, one commonly observed pattern has been a positive correlation between longer contract terms and lower annual rents. This indicates the presence of a buyer's market in the long-term LURT business. The disparity of the LURT rent price between short- and long-term contracts demonstrates the over-supply of long-term LURT contracts. On one hand, farmers earn less and also abstain from increases in land value with longer contract terms. The other aspect worthy of attention is the common un-satisfaction with the rents, from both farmers and contractors. Despite the fact that everybody prefers higher incomes, this un-satisfaction reflects that the prevailing low profit margins the agriculture sector as a whole. Third, as for public participation, many cases of LURT in this area were largely promoted by proactive local village leaders through intensive lobbying. Corresponding well to the customary top-down approach in China's administrative system, this phenomenon indicates the partial disregard for the demand of minority for the sake of the majority.

Through diverse contract modes, LURT is gaining its popularity in Zhangye City. Our survey results indicate the inner complexity of LURT system, with the core issue based on economic challenges. The future success of LURT requires more input on contract supervision, technical support from local authorities, increasing public awareness, protection of farmer's rights and the creation of a more profitable agricultural sector. In view of the similar conditions between the City of Zhangye and other cities located in Hexi Corridor, this study may serve as reference for furthering research on the socio-economic effect of LURT policy in the region.

\section{References}

Brandt, L., Huang, J., Li, G. and Rozelle, S. (2002) 'Land rights in rural China: facts, fictions and issues', The China Journal, Vol. 47, pp.67-97.

Carter, M.R. and Yao, Y. (2002). 'Local versus global separability in agricultural household models: The factor price equalization effect of land transfer rights'. American Journal of Agricultural Economics, Vol. 84, No. 3, pp.702-715.

Ding, C. (2003) 'Land policy reform in China: assessment and prospects', Land Use Policy, Vol. 20, No. 2, pp.109-120.

Ding, C. (2007) 'Policy and praxis of land acquisition in China', Land Use Policy, Vol. 24, No. 1, pp.1-13.

Du, G. (2012) Gaotaixian Nongcun Jingji Jiegou De Xianzhuang, Wenti Yu Duice [Current Status, Problem and Counterstrategy of Rural Economic Structure in Gaotai County] (In Chinese). Gaotai Statistics Bureau. Available at: http://www.zytj.gov.cn/web/Article/tjfx/2012/09/ 20/162.html (access 23 July 2015).

Du, Y. and Sun, B. (2011). 'The development of Chinese agricultural land transfer system: transaction, concentration and commercialization', Journal of Agricultural Science, Vol. 3, No. 3, p.269.

Hennink, M., Hutter, I. and Bailey, A. (2010) Qualitative Research Methods. Sage, SAGE Publications, London.

He. X. (2015) 'ZhaijidiTuichuYingshiYigeZirandeGuocheng' [Transformation of Rural House Site ought to be a natural process] (In Chinese). Available at: http://www.3nong.org/News/18.html (access 16 July 2015).

Ho, S.P. and Lin, G. (2003) 'Emerging land markets in rural and urban China: policies and practices', The China Quarterly, Vol. 175, pp.681-707. 
Gansu Rural Yearbook Committee (2010) Gansu Rural Yearbook 2009, Editorial Committee of Gansu Rural Yearbook, Lanzhou, p.210.

Gu, Y. (2003), 'ZhongguoTudiZhiduGaige' [Revolution of China's land institution] (In Chinese), News of Communist Party of China, http://cpc.people.com.cn/GB/64156/64157/4512167.html (access 20 July 2015).

Jiang, X., Liu, S. and Li, Q. (2007). 'Tudi Zhidu Gaige Yu Guomin Jingji Chengzhang' [Land Institution Reform and Development of National Economy] (In Chinese), Management World, Vol. 9, pp.1-9.

Krusekopf, C.C. (2002) 'Diversity in land-tenure arrangements under the household responsibility system in China', China Economic Review, Vol. 13, No. 2, pp.297-312.

Kung, J.K.S. (2000). 'Common property rights and land reallocations in rural China: evidence from a village survey', World Development, Vol. 28, No. 4, pp.701-719.

Li, G., Rozelle, S. and Brandt, L. (1998). 'Tenure, land rights, and farmer investment incentives in China', Agricultural Economics, Vol. 19, No. 1, pp.63-71.

Li, J. (2014) Gaotaixian Guanyu "Qiye+Zhibu+Nonghu+Jidi” Tudiliuzhuan Moshi De Diaoyan Baogao [A Report on the Land Use Right Transfer Mode in Gaotai County]. (In Chinese). Gaotai Statistics Bureau. Available at: http://www.zytj.gov.cn/web/Article/tjfx/2014/03/ 21/788.html (access 11 July 2015).

Liu, K. (2012) 'A case study of land transfer in rural China', Paper presented at International Conference on Land Grabbing II. Land Deals Politics Initiative (LDPI), September 2012, Cornell University, Ithaca, NY.

Liu, S., Carter, M.R. and Yao, Y. (1998) 'Dimensions and diversity of property rights in rural China: dilemmas on the road to further reform', World Development, Vol. 26, No. 10, pp.1789-1806.

National Bureau of Statistics of China (2004) China Statistical Yearbook 2003, China Statistics Press, Beijing, China, p.424, Table 12-14.

National Bureau of Statistics of China (2014) China Statistical Yearbook 2013, China Statistics Press, Beijing, China: Author, Table 13-3.

Qiao, B., Fang, C. and Huang, J. (2006) 'The coupling law and its validation of the interaction between urbanization and eco-environment in arid area'. Acta Ecologica Sinica, Vol. 26, No. 7, pp.2183-2190.

Sixteenth Central Committee of the Communist Party of China (2003) Zhonggong Zhongyang Guanyu Wanshan Shehuizhuyi Shichangjingji Tizhi Ruogan Wenti De Jueding[Decision of the Central Committee of the Communist Party of China on Some Issues concerning the Improvement of the Socialist Market Economy] (In Chinese). Available at: http://cpc.people.com.cn/GB/64162/64168/64569/65411/4429165.html (access 25 July 2015)..

Song, W., Chen, B., Yang, H. and Chen, X. (2008) 'Woguo Nongcun Zhaijidi Ziyuan Xianzhuang Fenxi' [Analysis on the Status Quo of Residence Base Resources in Rural Areas of China] (in Chinese). Chinese Journal of Agricultural Resources and Regional Planning, Vol. 29, No. 3, pp.1-5.

The National People's Congress (1954) Constitution of the People's Republic of China, Chapter 1, Article 8, 13. Beijing.

The National People's Congress (1975) Constitution of the People's Republic of China, Chapter 1, Article 6. Beijing.

The National People's Congress (1978) Constitution of the People's Republic of China, Chapter 1, Article 6, 7. Beijing.

The National People's Congress (1982) Constitution of the People's Republic of China, Chapter 1, Article 10.Beijing.

The National People's Congress (1988) Amendment to the Constitution of the People's Republic of China, Article 2. Beijing.

The National People's Congress (2004) Constitution of the People's Republic of China, Chapter 1, Article 10. Beijing. 
The National People's Congress (2004) Land Administration Law of the People's Republic of China, Chapter 2, Articles 14, 15. Beijing.

Wang, Y. (2014) Zhangyeshi Nongcun Tudiliuzhuan Cujin Shidu Guimojingying Diaoyan Baogao[A Report on the Promotion of Moderate Intensive Farming via Land Right Use Transfer in Rural Zhangye Area] (In Chinese). Zhangye Statistics Bureau. Available at: http://www.zytj.gov.cn/web/Article/tjfx/2014/09/30/1160.html (access 19 July 2015)

Xian, L. (2013) Gansu City Yearbook 2012, Gansu City Yearbook Committee, China Statistics Press, P.14.

Zhu, J. (2004) 'From land use right to land development right: institutional change in China's urban development', Urban Studies, Vol. 41, No. 7, pp.1249-1267.

Zhangye Agricultural Bureau (2015) 2015 Nian Woshi Yumizhizhong Chanyexingshi Xianghao[An Expected Boom of Seed Corn Production in City of Zhangye in 2015] (in Chinese). February 2, 2015. Available at: http://nyj.zhangye.gov.cn/Item/45104.aspx (access 24 July 2015).

\section{Notes}

1 The "mu" is a unit of area used in China where, $1 \mathrm{mu} \approx 666.67 \mathrm{~m}^{2}$

2 The only published data found on privately farmed plots estimates the 2002 per capita as $0.08 \mathrm{mu}$ (National Bureau of Statistics of China, 2004). This can be converted into a total area of $6.26 \times 10^{7} \mathrm{mu}\left(417.33 \times 10^{4} \mathrm{hm}^{2}\right)$.

3 Calculated from NH Town local government data. This figure stands for net LURT area at the end of 2013. 